\title{
Comparative Histological Studies of the Thyroid Gland of Lower Vertebrates
}

\author{
By \\ Yoshiaki Yamamoto \\ Department of Anatomy, Nagoya University School of Medicine \\ (Director: Prof. Dr. Shooichi Sugi y a ma)
}

\section{Introduction}

The thyroid gland of the lower vertebrate has attracted much attention in various fields of biology and medicine along physiological and biochemical lines (Goldsmith, '49 and Gorbman, '55b). Notwithstanding this, so far as the author is aware, there is little description of the comparative histology of the thyroid glands, excepting that of $\mathrm{Krause}$ ('23) and Tsu tsu i ('58). Guder nats ch ('11) published the comparative anatomical and histological results of the thyroid glands of bony fishes and $\mathrm{Hell} \mathrm{baum} \mathrm{('36)} \mathrm{described}$ histologically this gland in some kinds of snake, and Fors y th ('08) in many different species of bird. Even in the Handbücher, where S o b ot t a ('15) and B a r g mann ('39) deal with the thyroid gland, and further in E g g e r t's monograph ('38), there is no detailed description of its comparative histology. Gegenbaur ('01) in his textbook, Maurer ('06) in Hertwig's $\mathrm{Handbuch}$, Pisc h i n g e r ('37) in Bolk-Göppert's Handbuch and Gor b man ('55a) did not go further with this problem.

For this reason, the author undertook the present study with the hope of filling the gaps and presenting some new evidence on the structure of the thyroid glands of lower vertebrates. At the same time, the author intended, by comparing the present results with the data known of the thyroid glands of mammals, to consider the similarity and dissimilarity between the thyroid glands of the vertebrates.

\section{Material and Methods}

Materials consisted of the thyrojd glands of different species from different classes of fishes amphibians, reptiles and birds, indicated in 
table 1. These animals were collected in the Ise District (one of the littoral districts in Japan). The materials were fixed chiefly in Helly's, Ciaccio's, Bouin's and 10 per cent formol fluids, embedded in paraffin, and sectioned at 5 to $8 \mu$ serially and transversely. The sections prepared were stained mainly by Mayer's hematoxylin and eosin and $\mathrm{He}$ id e nhain's iron hematoxylin, sometimes by Weigert's resorcin fuchsin for demonstrating elastic fibers and by $\mathrm{B}$ i e l s c ho wsky's silver impregnation for argyrophilic fibers. Some of the sections fixed in Helly's or Ciaccio's fluid were stained by periodic acid-Schiff's technique in combination with saliva digestion for detecting glycogen and other substances. Dimensions of 100 follicles, large and small, regarded as representative, and heights and widths of follicle cells were measured by the usual mathod and averaged (table 1).

\section{Observations}

Bocy lengths, body weights and sexes of the animals used and date of sacrifice are shown in table 1 and will be discussed in relation to the histological findings presented here.

Birds-The thyroid glands of the birds examined were paired without the isthmus (W i edershei m, '06; Schimkewitsch, '10; P is chinger, '37), and showed almost the same position in various species. The glands were located at the beginning part of the neck, covered partly by the sternum. Both lobes lie, lateral to the trachea, on the ventral side of the carotis communis at a point where the carotis communis touches the jugular vein.

1. Crows-Corvus corone orientalis-Large and snall follicles were evenly distributed in the gland, and irregular-shaped follicles were scarce (fig. 1). The diameters are indicated in table 1. The follicles were completely separated and independent. Follicle cells were cubical (table 1). The nuclei were sjtuated basally and were round to oval. The chromatin reticulum was moderately dense and the nucleoli were indistinct. The cytoplasm was granular. No pigment granules nor secretory droplets were found in it. No parafollicular cells were found. Colloid was eosinophilic, homogeneous and periodic acid-Schiff positive. Desquamated follicle cells and erythrocytes were rarely found in it.

The capsule was less developed and no interlobular connective tissue was found (fig. 1). Argyrophilic fibers formed a thin layer 
Table 1. Histology of the thyroid glands of lower vertebrates. Dimensions averaged of 100 follicles, large and small, regarded as representative, heights and widths averaged of follicle cells, and occurrence of sphincter-apparata in arteries.

\begin{tabular}{|c|c|c|c|c|c|c|c|c|c|c|}
\hline & $\begin{array}{c}\text { Body } \\
\text { length } \\
\text { (cm) }\end{array}$ &.$\underset{\text { weight }}{\text { Bg }}$ & $\begin{array}{l}\text { Date of } \\
\text { sacrifice }\end{array}$ & 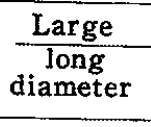 & $\begin{array}{c}\text { follicles } \\
\text { short } \\
\text { diameter }\end{array}$ & 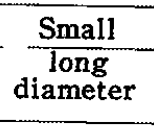 & $\begin{array}{c}\text { follicles } \\
\begin{array}{c}\text { short } \\
\text { diemeter }\end{array}\end{array}$ & $\begin{array}{l}\text { Follicle } \\
\text { height }\end{array}$ & $\frac{\text { cell }}{\text { width }}$ & $\begin{array}{c}\text { Sphincter } \\
\text { apparata } \\
\text { in arteries }\end{array}$ \\
\hline \multicolumn{11}{|l|}{$\begin{array}{l}\text { Birds: } \\
\text { Corvus corone orientalis }\end{array}$} \\
\hline $\begin{array}{l}\text { right } \\
\text { left } \\
\text { No. } 2(\mathrm{f}) \\
\text { No. } 3(\mathrm{~m})\end{array}$ & & $\begin{array}{r}550 \\
1000\end{array}$ & $\begin{array}{l}\text { June } 8 \\
\text { April } 16\end{array}$ & $\begin{array}{l}76 \mu \\
70 \\
93\end{array}$ & $\begin{array}{l}57 \mu \\
57 \\
64\end{array}$ & $\begin{array}{l}24 \mu \\
26 \\
33\end{array}$ & $\begin{array}{l}19 \mu \\
20 \\
23\end{array}$ & $\begin{array}{l}8 \mu \\
6 \\
8\end{array}$ & $\begin{array}{l}7 \mu \\
7 \\
7\end{array}$ & \\
\hline Columba livia domestica & & & - & $\begin{array}{l}97 \\
90\end{array}$ & $\begin{array}{l}71 \\
67\end{array}$ & $\begin{array}{l}25 \\
28\end{array}$ & $\begin{array}{l}20 \\
19\end{array}$ & $\begin{array}{l}6 \\
7\end{array}$ & $\begin{array}{l}7 \\
7\end{array}$ & \\
\hline $\begin{array}{l}\text { No. } 1(\mathrm{~m}) \\
\text { No. } 2(\mathrm{~m}) \\
\text { No. } 3(\mathrm{~m}) \\
\text { No. } 4(\mathrm{~m}) \\
\text { No. } 5(\mathrm{f}) \\
\text { No. } 6(\mathrm{f}) \\
\text { No. } 7(\mathrm{~m}) \\
\text { No. } 8(\mathrm{~m})\end{array}$ & & $\begin{array}{l}350 \\
320 \\
340 \\
340 \\
300 \\
300 \\
350 \\
350\end{array}$ & $\begin{array}{l}\text { Sept. } 30 \\
\text { Sept. } 30 \\
\text { Feb. } 18 \\
\text { Feb. } 18 \\
\text { Sept. 30 } \\
\text { Sept. 30 } \\
\text { Feb. } 18 \\
\text { Feb. } 18\end{array}$ & $\begin{array}{r}116 \\
93 \\
79 \\
83 \\
90 \\
96 \\
67 \\
73\end{array}$ & $\begin{array}{l}78 \\
72 \\
60 \\
55 \\
66 \\
70 \\
46 \\
52\end{array}$ & $\begin{array}{l}24 \\
23 \\
27 \\
24 \\
28 \\
23 \\
18 \\
20\end{array}$ & $\begin{array}{l}17 \\
20 \\
22 \\
21 \\
23 \\
19 \\
16 \\
18\end{array}$ & $\begin{array}{l}6 \\
7 \\
9 \\
9 \\
9 \\
6 \\
6 \\
6\end{array}$ & $\begin{array}{l}8 \\
7 \\
7 \\
6 \\
7 \\
8 \\
7 \\
7\end{array}$ & $\#$ \\
\hline $\begin{array}{l}\text { Gallus gallus domesticus } \\
\text { Embryos }\end{array}$ & & & & & & & & & & + \\
\hline $\begin{array}{l}12 \text { days } \\
8 \text { days } \\
5 \text { days }\end{array}$ & & $\begin{array}{r}4 \\
6\end{array}$ & $\begin{array}{l}\text { Sept. } 23 \\
\text { Sept. } 23\end{array}$ & 26 & 20 & 12 & 10 & $\begin{array}{l}6 \\
6\end{array}$ & $\begin{array}{l}6 \\
7\end{array}$ & \\
\hline $\begin{array}{r}\text { No. } 1 \\
\text { No. } 2 \\
\text { (before hatching) } \\
\text { Children }\end{array}$ & & $\begin{array}{l}10 \\
11\end{array}$ & $\begin{array}{l}\text { Sept. } 23 \\
\text { Sept. 23 }\end{array}$ & $\begin{array}{l}22 \\
23\end{array}$ & $\begin{array}{l}21 \\
19\end{array}$ & $\begin{array}{l}12 \\
12\end{array}$ & $\begin{array}{l}11 \\
10\end{array}$ & $\begin{array}{l}6 \\
5\end{array}$ & $\begin{array}{l}7 \\
7\end{array}$ & \\
\hline $\begin{array}{l}2 \text { days }(\mathrm{m}) \\
60 \text { days } \\
\text { No. } 1(f)\end{array}$ & & $\begin{array}{r}13 \\
420\end{array}$ & $\begin{array}{l}\text { Sept. } 23 \\
\text { Sept. } 23\end{array}$ & 34 & 26 & 15 & -12 & 5 & 7 & \\
\hline $\begin{array}{cc} & \text { right } \\
\text { left } & \text { No. } 2(f) \\
\text { Aduilts (f) } & \\
\text { Hirundo rustica gutturalis (m) } \\
\text { Passer montanus saturatus (m) } \\
\text { Reptiles: }\end{array}$ & & $\begin{array}{r}350 \\
1800 \\
16 \\
14\end{array}$ & $\begin{array}{l}\text { Sept. } 23 \\
\text { Sept. } 16 \\
\text { June } 16 \\
\text { April } 30\end{array}$ & $\begin{array}{r}76 \\
89 \\
110 \\
250 \\
42 \\
45\end{array}$ & $\begin{array}{r}47 \\
50 \\
76 \\
152 \\
32 \\
35\end{array}$ & $\begin{array}{l}23 \\
24 \\
26 \\
32 \\
17 \\
20\end{array}$ & $\begin{array}{l}19 \\
20 \\
21 \\
25 \\
13 \\
18\end{array}$ & $\begin{array}{l}7 \\
7 \\
6 \\
6 \\
6 \\
5\end{array}$ & $\begin{array}{l}6 \\
6 \\
7 \\
9 \\
6 \\
8\end{array}$ & $\#$ \\
\hline $\begin{array}{l}\text { Reptiles: } \\
\text { Clemmys japonica } \\
\text { Children }\end{array}$ & & & & & & & & & & + \\
\hline $\begin{array}{ll} & \text { No. } 1(\mathrm{f}) \\
& \text { No. } 2(\mathrm{~m}) \\
& \text { No. } 3(\mathrm{f}) \\
\text { Adults } & \text { No. } 4(\mathrm{f})\end{array}$ & $\begin{array}{l}4 \\
4.5 \\
3.5 \\
4\end{array}$ & & $\begin{array}{l}\text { July } 20 \\
\text { July } 20 \\
\text { April } 11 \\
\text { April } 11\end{array}$ & $\begin{array}{r}48 \\
143 \\
108 \\
121\end{array}$ & $\begin{array}{l}33 \\
83 \\
75 \\
67\end{array}$ & $\begin{array}{l}16 \\
40 \\
37 \\
39\end{array}$ & $\begin{array}{l}11 \\
29 \\
29 \\
27\end{array}$ & $\begin{array}{l}7 \\
8 \\
8 \\
7\end{array}$ & $\begin{array}{l}6 \\
7 \\
7 \\
7\end{array}$ & \\
\hline $\begin{array}{l}\text { No. } 1 \text { (f) } \\
\text { No. } 2 \text { (f) } \\
\text { No. } 3 \text { (f) } \\
\text { No. } 4 \text { (f) } \\
\text { No. } 5 \text { (f) } \\
\text { No. } 6 \text { (f) } \\
\text { Caretta caretta olivacea (f) } \\
\text { Gecko japonicus (f) } \\
\text { Eumeces latiscutatus latiscutatus (f) } \\
\text { Elaphe climacophora } \\
\text { No. } 1(\mathrm{~m})\end{array}$ & $\begin{array}{r}18 \\
17 \\
18 \\
19 \\
17 \\
19 \\
140 \\
9 \\
10\end{array}$ & 155000 & $\begin{array}{l}\text { July } 20 \\
\text { July } 20 \\
\text { July } 18 \\
\text { July } 18 \\
\text { July 18 } \\
\text { July 18 } \\
\text { Oct. 29 } \\
\text { May 23 } \\
\text { Aug. 20 }\end{array}$ & $\begin{array}{r}366 \\
538 \\
795 \\
610 \\
491 \\
595 \\
2480 \\
83 \\
58\end{array}$ & $\begin{array}{r}254 \\
349 \\
567 \\
412 \\
343 \\
420 \\
800 \\
63 \\
40\end{array}$ & $\begin{array}{r}82 \\
95 \\
151 \\
78 \\
82 \\
93 \\
80 \\
34 \\
25\end{array}$ & $\begin{array}{l}54 \\
62 \\
93 \\
53 \\
60 \\
64 \\
60 \\
28 \\
23\end{array}$ & $\begin{array}{r}11 \\
8 \\
13 \\
8 \\
17 \\
11 \\
9 \\
8 \\
7\end{array}$ & $\begin{array}{l}8 \\
8 \\
8 \\
8 \\
8 \\
8 \\
9 \\
9 \\
8\end{array}$ & $\begin{array}{l}- \\
-\end{array}$ \\
\hline $\begin{array}{l}\text { No. } 1(\mathrm{~m}) \\
\text { No. } 2(\mathrm{~m}) \\
\text { No. } 3(\mathrm{f}) \\
\text { No. } 4(\mathrm{f}) \\
\text { No. } 5(\mathrm{f}) \\
\text { No. } 6(\mathrm{f}) \\
\text { No. } 7(\mathrm{f}) \\
\text { No. } 8(\mathrm{f}) \\
\text { No. } 9(\mathrm{f}) \\
\text { No. } 10(\mathrm{f}) \\
\text { Elaphe quadrivirgata }\end{array}$ & $\begin{array}{r}122 \\
88 \\
96 \\
98 \\
146 \\
145 \\
160 \\
174 \\
120 \\
163\end{array}$ & & $\begin{array}{l}\text { May 15 } \\
\text { April. 30 } \\
\text { March 15 } \\
\text { March 15 } \\
\text { Aug. 1 } \\
\text { Sept. 3 } \\
\text { Aug. 27 } \\
\text { June 28 } \\
\text { June 25 } \\
\text { June 18 }\end{array}$ & $\begin{array}{l}303 \\
282 \\
450 \\
516 \\
407 \\
388 \\
350 \\
428 \\
279 \\
656\end{array}$ & $\begin{array}{l}202 \\
192 \\
288 \\
333 \\
284 \\
237 \\
237 \\
276 \\
186 \\
452\end{array}$ & $\begin{array}{l}59 \\
54 \\
69 \\
71 \\
56 \\
60 \\
68 \\
66 \\
64 \\
67\end{array}$ & $\begin{array}{l}40 \\
34 \\
43 \\
41 \\
38 \\
39 \\
48 \\
42 \\
44 \\
44\end{array}$ & $\begin{array}{r}7 \\
7 \\
11 \\
9 \\
8 \\
12 \\
12 \\
8 \\
9 \\
10\end{array}$ & $\begin{array}{l}7 \\
8 \\
7 \\
8 \\
8 \\
7 \\
7 \\
8 \\
7 \\
8\end{array}$ & .. \\
\hline $\begin{array}{l}\text { No. } 1(\mathrm{~m}) \\
\text { No. } 2(\mathrm{f}) \\
\text { No. } 3(\mathrm{f}) \\
\text { No. } 4(\mathrm{f}) \\
\text { No. } 5(\mathrm{f}) \\
\text { Elaphe conspicillata (f) } \\
\text { Natrix vibakari vibakari (f) } \\
\text { Natrix tigrina tigrina } \\
\text { No. } 1(\mathrm{f})\end{array}$ & $\begin{array}{r}98 \\
110 \\
96 \\
103 \\
80 \\
130 \\
100 \\
90\end{array}$ & . & $\begin{array}{l}\text { Aug. } 15 \\
\text { June } 13 \\
\text { Aug. } 15 \\
\text { Oct. } 2 \\
\text { Sept. } 3 \\
\text { Dec. } 27 \\
\text { Aug. } 16\end{array}$ & $\begin{array}{l}759 \\
430 \\
305 \\
310 \\
260 \\
420 \\
442 \\
\end{array}$ & $\begin{array}{l}504 \\
302 \\
199 \\
214 \\
173 \\
296 \\
313\end{array}$ & $\begin{array}{r}110 \\
66 \\
61 \\
72 \\
51 \\
71 \\
76\end{array}$ & $\begin{array}{r}55 \\
44 \\
43 \\
45 \\
35 \\
46 \\
49 \\
-\end{array}$ & $\begin{array}{r}7 \\
13 \\
13 \\
9 \\
8 \\
8 \\
8\end{array}$ & $\begin{array}{l}7 \\
7 \\
6 \\
7 \\
7 \\
8 \\
9\end{array}$ & $\begin{array}{l}- \\
-\end{array}$ \\
\hline $\begin{array}{c}\text { No. } 1(\mathrm{f}) \\
\text { No. } 2(\mathrm{f}) \\
\text { No. } 3(\mathrm{~m}) \\
\text { No. } 4(\mathrm{f}) \\
\begin{array}{c}\text { Agkistrodon blomhoffii } \\
\text { Embryos }\end{array}\end{array}$ & $\begin{array}{l}90 \\
95 \\
80 \\
80\end{array}$ & & $\begin{array}{l}\text { July } 16 \\
\text { July } 16 \\
\text { Aug. } 23 \\
\text { Aug. } 23\end{array}$ & $\begin{array}{l}412 \\
331 \\
372 \\
423\end{array}$ & $\begin{array}{l}318 \\
206 \\
283 \\
290\end{array}$ & $\begin{array}{l}68 \\
62 \\
63 \\
66\end{array}$ & $\begin{array}{l}41 \\
41 \\
41 \\
42\end{array}$ & $\begin{array}{l}8 \\
7 \\
7 \\
7\end{array}$ & $\begin{array}{l}7 \\
7 \\
7 \\
7\end{array}$ & \# \\
\hline $\begin{array}{ll} & \text { No. } 1 \text { (f) } \\
\text { Adults } & \text { No. } 2 \text { (f) }\end{array}$ & $\begin{array}{l}15 \\
15\end{array}$ & & $\begin{array}{l}\text { Aug. } 23 \\
\text { Aug. } 23\end{array}$ & $\begin{array}{l}80 \\
81\end{array}$ & $\begin{array}{l}54 \\
55\end{array}$ & $\begin{array}{l}39 \\
37\end{array}$ & $\begin{array}{l}30 \\
30\end{array}$ & $\stackrel{9}{9}$ & $\begin{array}{l}6 \\
6\end{array}$ & \\
\hline $\begin{array}{ll}\text { Adults } & \text { No. } 1(\mathrm{f}) \\
& \text { No. } 2(\mathrm{f}) \\
& \text { No. } 3(\mathrm{f}) \\
& \text { No. } 4(\mathrm{f}) \\
& \text { No. } 5(\mathrm{~m}) \\
\text { Amphibians : } & \text { No. } 6(\mathrm{f})\end{array}$ & $\begin{array}{l}57 \\
47 \\
50 \\
42 \\
46 \\
50\end{array}$ & & $\begin{array}{l}\text { Aug. } 23 \\
\text { May } 30 \\
\text { May } 30 \\
\text { Sept. } 18 \\
\text { Sept. } 18 \\
\text { Sept. } 18\end{array}$ & $\begin{array}{l}302 \\
326 \\
324 \\
301 \\
429 \\
337\end{array}$ & $\begin{array}{l}208 \\
231 \\
245 \\
215 \\
327 \\
239\end{array}$ & $\begin{array}{l}57 \\
82 \\
82 \\
65 \\
68 \\
65\end{array}$ & $\begin{array}{l}35 \\
57 \\
57 \\
40 \\
41 \\
44\end{array}$ & $\begin{array}{r}7 \\
18 \\
15 \\
11 \\
10 \\
10\end{array}$ & $\begin{array}{l}6 \\
8 \\
9 \\
7 \\
7 \\
7\end{array}$ & \\
\hline $\begin{array}{l}\text { Amphibians: } \\
\text { Triturrus pyrrhogaster } \\
\text { No. } 1(f) \\
\text { No. } 2(f) \\
\text { Onychodactylus japonicus }\end{array}$ & $\begin{array}{r}10 \\
9\end{array}$ & & $\begin{array}{ll}\text { July } & 20 \\
\text { July } & 20\end{array}$ & $\begin{array}{l}353 \\
215\end{array}$ & $\begin{array}{r}85 \\
124\end{array}$ & $\begin{array}{l}73 \\
63\end{array}$ & $\begin{array}{l}32 \\
48\end{array}$ & 9 & 16 & - \\
\hline $\begin{array}{r}\text { No. } 1 \text { (f) } \\
\text { No. } 2(\mathrm{f}) \\
\text { Rana nigromaculata nigromaculata }\end{array}$ & $\begin{array}{l}11 \\
10\end{array}$ & & $\begin{array}{l}\text { June } 13 \\
\text { June } 13\end{array}$ & $\begin{array}{l}187 \\
205\end{array}$ & $\begin{array}{l}117 \\
126\end{array}$ & $\begin{array}{l}74 \\
82\end{array}$ & $\begin{array}{l}41 \\
56\end{array}$ & $\begin{array}{l}12 \\
12\end{array}$ & $\begin{array}{l}10 \\
11\end{array}$ & - \\
\hline $\begin{array}{l}\text { No. } 1(f) \\
\text { Hola } 2 \text { (f) } \\
\text { Bony fishes: }\end{array}$ & $\begin{array}{l}8 \\
7 \\
2.5\end{array}$ & & $\begin{array}{l}\text { Aug. } 10 \\
\text { Aug. } 10 \\
\text { June } 29\end{array}$ & $\begin{array}{r}189 \\
153 \\
72\end{array}$ & $\begin{array}{l}65 \\
88 \\
44\end{array}$ & $\begin{array}{l}50 \\
42 \\
36\end{array}$ & $\begin{array}{l}23 \\
27 \\
23\end{array}$ & $\begin{array}{l}8 \\
6\end{array}$ & $\begin{array}{r}10 \\
8\end{array}$ & - \\
\hline $\begin{array}{l}\text { Plecoglossus altivelis (f) } \\
\text { Goldfish (f) } \\
\text { Oryzias latipes (f) } \\
\text { (Killi fish) }\end{array}$ & $\begin{array}{l}15 \\
10 \\
2.7\end{array}$ & & $\begin{array}{l}\text { Sept. } 13 \\
\text { July } 19 \\
\text { May } 23\end{array}$ & $\begin{array}{l}94 \\
83 \\
70\end{array}$ & $\begin{array}{l}64 \\
54 \\
41\end{array}$ & $\begin{array}{l}32 \\
19 \\
21\end{array}$ & $\begin{array}{r}24 \\
13 \\
7\end{array}$ & $\begin{array}{l}4 \\
3 \\
3\end{array}$ & $\begin{array}{l}6 \\
7 \\
6\end{array}$ & $\bar{z}$ \\
\hline
\end{tabular}

(f): female; (m): male 
directly around the follicles. Arteries ran beneath or within the capsule and most of them entered the interior of the gland to ramify into smaller branches. At their branching points, the sphincter apparata which consisted of endothelium and smooth muscle fibers circularly arranged, were often found (fig. 16). Their apex projected towards the cavity of the mother artery and their base situated on the branching point. Veins were accompanied by the arteries and had no muscle fibers. Capillaries formed networks around follicles accompanying the argyrophilic fibers. Some of them became like sinusoids. All these patterns of blood vessels were maintained in almost the same manner in the other species examined.

2. Pigeons-Columba livia domestica-Follicles were larger in the peripheral zone of the gland than in the central zone. The diameters are indicated in table 1. Follicles were generally round to oval, but were often very irregular-shaped in one of the cases exmined. Several follicles were associated with others without open communication of their cavities. Follicle cells were cubical to columnar, and lower in peripheral large follicles (table 1). The nuclei were round to oval and situated in the basal zone of the cell. The chromatin reticulum was moderately dense and the nucleoli were indistinct. The cytoplasm was granular and contained no pigment granules. No parafollicular cells were found. Colloid was periodic acid-Schiff positive, homogeneous, less vacuolated, and contained no desquamated cells nor erythrocytes.

The capsule was relatively well developed and contained fat tissue, argyrophilic fibers and small amounts of elastic fibers. The interstitial connective tissue was less developed, but contained argyrophilic fibers with no elastic fibers. No interlobular connective tissue was formed. Lymphoid tissue islets were sometimes found between follicles. Sphincter apparata were often found at the branching points of arteries.

3. Domestic Iowls-Gallus gallus domesticus-Follicles were larger at the periphery of the gland than at the center. The diameters are inaicated in table 1 . Follicles were generally round to oval and were completely separated. Before hatching they often connected with each other to form chains and conglomerates, without open communication of their cavities. Follicle cells were cubical to columnar and sometimes squamous in peripheral large follicles (table 1). The nuclei were round to oval and situated basally or centrally. The chromatin reticulum was moderately dense and the 
nucleoli were indistinct. The cytoplasm was granular, but contained neither secretory droplets nor pigment granules. Mitotic figures were found only in the embryonic glands. No parafollicular cells were found. Colloid was eosinophilic, homogeneous, less vacuolated, and contained no desquamated follicle cells nor erythrocytes.

The capsule was relatively well developed, containing argyrophilic fibers, small amounts of elastic fibers and iat tissue. Lymphoid tissue was often found here, especially around the veins. No interlobular connective tissue was found. The interstitial connective tissue contained abundant argyrophilic fibers, which formed a thin layer directly around the follicles. Blood vessels entered the interior of the gland in the same manner as found in the thyroid glands of pigeons. Perifollicular capillaries formed networks also in the same manner. Sphincter apparata were less often found at the branching points of the arteries.

4. Swallows-Hirundo rustica gutturalis-Large and small follicles were distributed also evenly throughout the gland, and irregularshaped follicles were scarce (fig. 2). The diameters are indicated in table 1 . Some of the follicles were connected without open communication of their cavities. Follicle cells were cubical (table 1). The nuclei were round to oval, and situated basally. The chromatin reticulum was moderately dense and the nucleoli indistinct. The cytoplasm was granular and contained no pigment granules nor secretory droplets. No parafollicular cells were found. Colloid was eosinophilic, homogeneous and less vacuolated. Neither desquamated follicle cells nor erythrocytes were found in it.

The capsule was less developed and no interlobular connective tissue was found. Argyrophilic fibers enclosed directly the follicles as a thin layer. Blood vessels found within the gland or in the capsule were relatively developed. At the branching points of the arteries, sphincter apparata were often found (fig. 17) and showed the same structure as were found in crows.

5. Sparrows-Passer montanus saturatus-Large and small follicles were evenly distributed in the gland and generally round to oval in shape (fig. 3). The diameters are indicated in table 1. Follicle cells were low cubical (table 1). The nuclei indicated almost the same appearance as shown in swallows and crows. No mitotic figures were found. No parafollicular cells were found. Colloid was eosinophilic, homogeneous and less vacuolated. Desquamated follicle cells were rarely found and no erythrocytes found in it. 
The capsule was less developed but contained abundant fat tissue and large blood vessels. Sphincter apparata were found often at the branching points of the arteries (fig. 18) and indicated the same structure as found in crows and swallows.

Reptiles-The thyroid glands of Chelonia were found as an unpaired oval platelet, directly ventral to the trachea, over the base of the heart or the beginning parts of the great vessels arising from the heart (Wiedersheim, '06; Schimkewitsch, '10). The thyroid glands of lizards were found as an unpaired long bridge running between both jugular veins, rostral to the heart and ventral to the trachea ( $\mathrm{S} \mathrm{chimkewits} \mathrm{ch}$, '10). The middle part of the bridge was constricted to an isthmus. The thyroid glands of snakes were found as an unpaired ovoid body anterior to the trachea between both jugular veins, and their anterior surface was covered by the thymus.

Clemmys japonica-Follicles were generally round to oval, and larger in the periphery of the gland than in the center (fig. 4). They were not associated with each other even in infant animals (fig. 5). A considerable number of follicles were irregular-shaped, with nipplelike folds of the follicle wall. The diameters are indicated in table 1. Follicle cells were generally high columnar in adults, but were cubical in infants (table 1). The nuclei were round and situated in the basal portion of the cell. The chromatin reticulum was moderately dense and the nucleoli were indistinct. The cytoplasm was granular and contained no pigment granules nor secretory droplets. Some of the follicle cells were clearly swollen and cask-like. There were rarely found colloid cells, whose cell body was periodic acidSchiff positive. No parafollicular cells were found. Colloid was eosinophilic, homogeneous and periodic acid-Schiff positive. Desquamated follicle cells and erythrocytes were rarely found in it.

The capsule was well developed, containing many arteries and veins. No interlobular connective tissue was found. Argyrophilic fibers formed a distinct layer directly around follicles (fig. 4). Elastic fibers were found in small amounts in the capsule but not within the gland. The arteries had rarely sphincter apparata in their branching points (fig. 21).

Follicle-like structures were found sometimes in the capsule (fig. 14). The structures were round to oval cysts filled with cellular detrituses, degenerating cells, and crystalloid, and were different in size $(140 \mu \times 140 \mu ; 240 \mu \times 140 \mu ; 110 \mu \times 90 \mu)$. They consisted of 
single- or double-layered cubical epithelium and stratified columnar epithelium with ciliated cells.

Logger-headed turtles-Caretta caretta olivacea-Follicles were extremely irregular-shaped and not associated with each other. The diameters are indicated in table 1. The follicles were of such irregular shapes as clover-leaves, dumb-bells, amoeba, ginko-leaves, maple-leaves, S-, Y-, and U- letters, and sometimes found with several nipple-like fola's or with pockets of the follicle wall. Some of the folds were $800 \mu$ in length and 60 to $30 \mu$ in width. These follicles were shown as closed multilocular sacs. Some of them had many small globular pockets in the walls, which communicated with the main cavities (fig. 22). Follicle cells were cubical to columnar (table 1). They were not always uniform in type in the same or one follicle, being columnar in some places and cubical in other places. Especially in folds and in small pockets of the follicle walls, they were highly columnar (fig. 22). The nuclei were round to oval. The chromatin reticulum was moderately dense and the nucleoli were indistinct. Some of the follicle cells appeared definitely swollen and cask-like. No parafollicular cells were found. Colloid was homogeneous and contained numerous degenerating follicle cells.

The capsule and interstitial connective tissue were well developed. The interlobular connective tissue was relatively distinct in the peripheral zone of the gland. Argyrophilic fibers surrounded follicles as a thick layer directly. No elastic fibers were found in the perifollicular tissue. Blood vessels showed no characteristics. No sphincter apparata were found.

Gecko japonicus-Follicles were round to oval, rarely irregularshaped, and larger in the peripheral zone of the gland than in the central zone (fig. 9). The diameters are indicated in table 1. Follicle cells were cubical (table 1). The nuclei were round to oval. The chromatin reticulum was moderately dense and the nucleoli were inaistinct. No mitotic figures were found. The cytoplasm was granular. No pigment granules were found but often secretory droplets in it. No parafollicular cells were found. Colloid was eosinophilic, homogeneous and less vacuolated. Desquamated follicle cells were sometimes found in it.

The capsule was less developed, and the interstitial connective tissue was little in amount. They contained no elastic fibers. Eosinophiles were often found. No sphincter apparata were found at the branching points of the arteries. 
Eumeces latiscutatus latiscutatus-Follicles were round to oval, rarely irregular-shaped, and large and small follicles were evenly distributed in the gland (fig. 8). The diameters are indicated in table 1. Follicle cells were cubical (table 1). The nuclei were round to oval and situated basally. The chromatin reticulum was moderately dense and the nucleoli were indistinct. The cytoplasm was finely granular and contained no pigment granules nor secretory droplets. No parafollicular cells were found. Colloid was eosinophilic, homogeneous and moderately vacuolated, and contained no erythrocytes and desquamated follicle cells.

The capsule and interstitial connective tissue were much less developed (fig. 8). No arteries nor veins were found in the gland, while the capillaries were well developed forming dense networks directly around follicles, and sometimes appeared like sinusoids. No sphincter apparata were found.

Elaphe climacophora-Follicles were polyhedral, completely separated, and larger in the peripheral zone of the gland than in the central zone. The diameters are indicated in table 1. In some of the cases examined, follicles were very irregular-shaped, and were often multilocular. Follicle cells were cubical to high columnar (table 1). The nuclei were round to oval and situated basally. The chromatin reticulum was moderately dense and the nucleoli were indistinct. The cytoplasm was finely granular and contained no secretory droplets nor pigment granules. There were rarely found large clear follicle cells singly or in groups among follicle cells. and whose cell body was cask-like and roughly granular. Their nuclei were displaced to the apical portion of the cell and sometimes were pyknotic. No parafollicular cells were found. Colloid was periodic acid-Schiff positive, homogeneous and little vacuolated but sometimes finely granular.

The capsule was relatively well developed, but the interstitial connective tissue was less developed. Argyrophilic fibers formed a thin layer, sometimes with a few elastic fibers directly, around the follicles. In the branching points of the arteries, there were very often found sphincter apparata (fig. 20).

Cysts and pearls were found in groups within the gland (fig. 15). The epithelium was stratified in the cysts and concentrically arranged in the pearls. It was further clearly swollen and partly degenerative.

Elaphe quadrivirgata-Follicles was completely separated from 
each other, polyhedral, but irregular-shaped in a considerable number, and larger in the peripheral zone of the gland than in the central zone. The diameters are indicated in table 1. Follicle cells were low cubical to high columnar (table 1 ). The nuclei were round to oval and situated basally. The chromatin reticulum was moderately dense and the nucleoli were indistinct. The cytoplasm contained often secretory droplets surrounded by a clear ring, or a large vacuole in the supranuclear zone. Brown pigment granules were found also in the same zone in some case. Colloid was eosinophilic, homogeneous and less vacuolated. It was periodic acid-Schiff positive and sometimes granular.

The capsule and the interstitial connective tissue were less developed. No interlobular connective tissue was found. Argyrophilic fibers formed a thin layer, together with a few elastic fibers directly around the follicles. Blood vessels of the gland showed no characteristic. No sphincter apparata were found in the arteries.

Elaphe conspicillata-Follicles were polyhedral, and separated from each other completely (fig. 6). They were large in the peripheral zone of the gland than in the central zone. The diameters are indicated in table 1. Nipple-like folds of the follicle walls were relatively often found. Follicle cells were generally cubical (table 1). They were sometimes squamous to low cubical. The nuclei were found the same in appearance as in other Elaphes. The cytoplasm was finely granular without containing secretory droplets. Colloid was eosinophilic, homogeneous and contained no desquamated follicle cells and no erythrocytes.

The capsule and the interstitial connective tissue were less developed. Argyrophilic fibers formed a thin layer directly around the follicles (fig. 6). No sphincter apparata were found at the branching points of the arteries.

Natrix tigrina tigrina-Follicles were polyhedral, larger in the peripheral zone of the gland than in the central zone. Small nippielike folds or pockets of the follicle wall were often seen, but no formation of new follicles was found here. The diameters are indicated in table 1. Follicle cells were cubical to columnar (table 1). The nuclei were round to oval but often irregular-shaped. The cytoplasm was eosinophilic and often loaded with large periodic acid-Schiff positive droplets in the lateral and basal portion of the cell (fig. 23). Brown pigment granules were found in the supranuclear zone in some cases. No parafollicular cells were found. Colloid 
showed no characteristic difference in appearance from that of other snakes, and was periodic acid-Schiff positive.

The capsule and the interstitial connective tissue were relatively developed. Argyrophilic fibers surrounded follicles directly as a thin layer. Blood vessels found in the capsule and the gland were also relatively developed. No sphincter apparata were found at the branching points of the arteries.

Natrix vibakari vibakari-Follicles were polyhedral, and larger in the peripheral zone of the gland than in the central zone. Some of the follicles seen in the central zone of the gland were tubule-like, or contained several small pockets. The diameters are indicated in table 1. Follicle cells were generally cubical (table 1). The nuclei were round to oval, and situated basally. The chromatin reticulum was moderately dense and the nucleoli were indistinct. The cytoplasm was eosinophilic and granular, and contained no pigment granules. No parafollicular cells were found. Colloid was eosinophilic and homogeneous, and no desquamated follicle cells nor blood cells were found in it.

The capsule and the interstitial connective tissue were less developed, and no interlobular connective tissue was found. Blood vessels showed no characteristic difference from those of other snakes. No sphincter apparata were found.

Agkistrodon blomhoffii-In adults, follicles were polyhedral and separated from each other completely, but in embryos they often were connected with each other without open communication of their cavities. They were larger in the peripheral zone of the gland than in the central zone (fig. 7). Some were so irregular-shaped as to be constricted at the middle, or with various-sized nipplelike inward and outward projecting folds of the wall. Small inward projecting folds were often caused by engorged capillaries. The diameters are indicated in table 1. Follicle cells were generally columnar (table 1). The nuclei were round to oval and situated basally. The chromatin reticulum was moderately dense and the nucleoli were indistinct. The cytoplasm was eosinophilic granular. In some case, it contained large vacuoles in the supranuclear zone. No parafollicular cells were found. Colloid showed almost the same appearance as shown in other snakes and was periodic acid-Schiff positive.

The capsule and the interstitial connective tissue were less developed (fig. 7). No interlobular connective tissue was found in the 
gland (fig. 7). Small amounts of elastic fibers were in the capsule but not in the interstitial connective tissue. Argyrophilic fibers surrounded follicles directly as a thin layer. Sphincter apparata were well devoloped (fig. 19) and occurred very often at the branching points of the arteries in the capsule and within the gland.

Amphibians - In amphibians, the thyroid gland appeared as paired bodies, which are situated in the angle between the internal and external carotid arteries arising from the foremost arch of the Truncus arteriosus.

Rana nigromaculata nigromaculata-Follicles were generally round to oval and separated from each other completely. Large follicles were more often found in the central zone of the gland and irregular-shaped. Some irregular-shaped follicles had a few pockets in the wall. The diameters are indicated in table 1. Follicle cells were cubical (table 1). The nuclei were round to oval and situated basally. The chromatin reticulum was moderately dense with distinct chromatin particles and the nucleoli were relatively distinct. The cytoplasm was roughly granular especially in the supranuclear zone. No parafollicular cells were found. Colloid was eosinophilic, homogeneous and less vacuolated. No desquamated follicle cells and no erythrocytes were lound in it.

The capsule and the interstitial connective tissue were far less developed. The latter contained fat tissue which filled the interfollicular spaces. Argyrophilic fibers surrounded follicles directly as a thin layer.

Hyla arborea japonica-Follicles was round to oval and rarely irregular-shaped, and completely separated from each other. Large and small follicles were almost evenly distributed in the gland (fig. 11). The diameters are indicated in table 1. Follicle cells were generally cubical (table 1). The nuclei were round to oval. The chromatin reticulum was moderately dense with aistinct chromatin particles but the nucleoli were indistinct. The cytoplasm was eosinophilic and granular. Mitotic figures were sometimes found. No parafollicular cells were found. Colloid was eosinophilic, homogeneous and less vacuolated.

The capsule and the interstitial connective tissue were less developed (fig. 11). Argyrophilic fibers surrounded follicles as a thin layer (fig. 11). No sphincter apparata were found in the arteries of the gland.

Triturrus pyrrhogaster-Follicles were oval, and rarely irregular- 
shaped with nipple-like folds of the wall. The follicles were completely separated and larger in the peripheral zone of the gland. The diameters are indicated in table 1. Follicle cells were low cubical (table 1). The nuclei were oval. The chromatin reticulum was moderately dense with distinct chromatin particles, and the nucleoli were indistinct. No parafollicular cells were found. Colloid was eosinophilic, homogeneous and less vacuolated. No desquamated cells and no erythrocytes were found in it.

The capsule was far less developed. The interstitial connective tissue was arranged loosely between follicles. No arteries and no veins were found in the gland.

Onychodactylus japonicus-Follicles were round to oval, rarely irregular-shaped. The follicles were larger in the peripheral zone of the gland. The diameters are indicated in table 1. Follicle cells were large and cubical to columnar (table 1). The nuclei were large and round to oval, and situated basally and larger in size than those of the other species (fig. 10). The chromatin reticulum was moderately dense and the nucleoli were indistinct. The cytoplasm was eosinophilic and granular, loaded with a few secretory droplets in the lateral portion of the cell. No parafollicular cells were found. Colloid was eosinophilic, homogeneous and less vacuolated. No desquamated cells and no erythrocytes were found in it.

The capsule was far less developed. The interstitial connective tissue was small in amount and arranged loosely. Argyrophilic fibers surrounded directly the follicles as a thin layer. No sphincter apparata were found in the arteries of the gland.

Bony fishes-The thyroid gland did not appear as an encapsulated organ (figs. 12 and 13), but the follicles were distributed singly or in groups along the ventral aorta.

In killi fishes (Oryzias latipes), follicles were round to oval. The diameters are indicated in table 1. Follicle cells were cubical (table 1). The nuclei were round to oval. The chromatin reticulum was moderately dense, and the nucleoli were indistinct. The cytoplasm was eosinophilic and granular. No parafollicular cells were found. Colloid was eosinophilic and less vacuolated. No desquamated follicle cells and no erythrocytes were found in it.

In gold fishes and Plecoglossus altivelis, follicles, follicle cells and colloid all indicated almost the same appearance in principle as in killi fishes. The diameters are indicated in table 1. Follicle cells were low cubical (table 1). No parafollicular cells were found. 


\section{Discussion}

Follicles-In the bony fishes examined, it was found that follicles are not gathered in an organ enclosed by the capsule, but rather scattered singly or in groups in connective tissue found along the ventral aorta (Gudernatsch, '11; Krause, '23; $\mathrm{Bargmann}$, '39) (figs. 12 and 13). In the other classes bigher than fishes, follicles are gathered always in an organ.

The distribution of follicles, large and small, is somewhat different from species to species. Most of the species examined indicated that large follicles are more frequent in the perjpheral zone of the gland. It has been rarely found in mammals that large follicles are usually distributed in the central zone ( $\mathrm{S} \mathrm{u} \mathrm{g}$ i y a m a and $\mathrm{S}$ a to, '54 in guinea pigs). Also in lower vertebrates it was so rare that this pattern was found only in Rana nigromaculata nigromaculata. On the other hand, some species of birds (crows, swallows and sparrows), reptiles (Eumeces latiscutatus latiscutatus) and amphibians (Hyla arborea japonica), which have generally small bodies, indicated an even distribution of large and small follicles in the glands (figs. 1, $2,3,8$ and 11 ).

The size of follicles depends upon the age of animals, the species and the functional state of the gland, and further varies from individual to individual. In birds it has been reported by $\mathrm{Be} \mathrm{nazzi}$

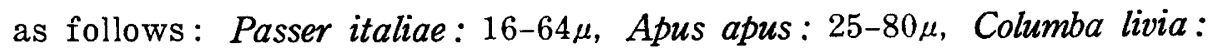
25-64 $\mu$, Mareca penelope : 30-90 $\mu$, Ardea purpurea : 32-125 $\mu$, Gallus gallus : $32-48 \mu$, Tinnunculus alandarius : $32-90 \mu$, Corbus corax : $45-120 \mu$, Meleagris gallopavo: $32-190 \mu$. Novotni ('31) reported the size of follicles of domestic fowls to be $1700 \mu$ in adults and 47 to $98 \mu$ in the young. In reptiles, it has been reported as follows: Naccarati ('22) found it to be 50 to $300 \mu$ in Emys europaea, and B o u rne ('35) to be 30 to $240 \mu$ in Egernia kingii. According to G a le ot t i (1897) and $\mathrm{B}$ a r g m a n ('39), the thyroid gland of tortoises contains voluminous follicles. The follicles of Rana esculenta showed diameters of 300 to $400 \mu$ ( $\mathrm{Kr}$ a u s e, '23). G u d e r n a t s c h ('11) investigated the size of follicles in different bony fishes. According to him, giant follicles are $700 \mu$-long by $400 \mu$ broad in Tautoga onitis and $1000 \mu$ in diameter in Pseudopleuronectes. K ra u s ('23) described that the follicles of Esox lucius reach $300 \mu$ in diameter. A d d is o $\mathrm{n}$ and $\mathrm{R} \mathrm{i} \mathrm{c} \mathrm{h} \mathrm{te} \mathrm{r} \mathrm{('32)}$ found several millimeter-long follicles in the thyroid gland of Xiphias gladius. Schatif er ('06) found the general size of follicles to be 
$126 \mu \times 234 \mu$ in Myxine. Fergus o n (10/11) described the different diameters of follicles in thyroid glands of Elasmobranchs.

The present study indicated some interesting data (table 1). In birds, animals of large size have larger follicles than those of small size. Furthermore, it may be sajd in lower vertebrates that the follicles generally depend upon the size of the animal body regardless of the species and age of animals used. Significant seasonal difference or sex difference in the general size of follicles were difficult to find. By comparing with the data of mammals ( $Y$ a $g$ i$\mathrm{z}$ a $\mathrm{w}$ a, '56), it is apparent that birds have far smaller follicles than small mammals such as rodents which have almost the same body weight. In reptiles it was found that: Caretta caretta olivacea have numerous far large follicle averaging $2480 \mu \times 800 \mu$. Snakes and Clemmys have generally larger follicles than domestic mammals which Yagizawa ('56) studied, and showed dominant occurrence of large follicles per unit area (figs. 4, 6 and 7). Bozzi (1895) obtained similar data that follicles of birds and amphibians are small while those of reptiles large. However, it was found that in small reptiles (Gecko and Eumeces latiscutatus latiscutatus) the follicles become smaller in size.

Most of the follicles in the lower vertebrates examined here are generally round to oval and this is in agreement with data obtained by different investigators ( $\mathrm{S} \mathrm{ch}$ a $\mathrm{f} \mathrm{fer}$, '06, Myxine; B i o n d i, 1888, amphibians and birds; $\mathrm{N}$ a c c a rat i, '22, Emys europaea; F e r g uso n, '10/11, sharks; Uhle $\mathrm{nhuth}$ and $\mathrm{Karns,} \mathrm{'27,} \mathrm{Amblystoma}$ maculatum; M a u r e r, 1899, lizards ; K r a u s e, '23, lower vertebrates ; Gudernatsch, '11, bony fishes). It has been found also that irregularshaped follicles occur more or less extensively in the thyroid gland of the lower vertebrates. A considerable number of investigators have pointed out various factors that influence the shape of follicles in thyroid glands of higher and lower vertebrates. Increase and decrease of follicle colloid lead follicles to irregularity (Sobotta, '15). Cowdry ('34) suggested that follicles become very irregular in hyperactivity of the gland. C harip per ('29) expressed almost the same view with amphibian thyroid glands (Necturus maculotus) and Gas c a ('32) with those of ducks. W e g e l in ('26) interpreted the irregular shape of follicles to be caused by fusion and division of follicles. On the other hand, it was found that the shape of follicles is related to the age of animals (Ge uer, '31, horses; Uhle nhuth and Karns, '27, Amblystoma maculatum). Gud e r- 
$\mathrm{n}$ at s c h ('11) stated that the ramification of follicles depends upon the species in fishes.

$\mathrm{Sch}$ af f e r ('06) found in Myxine irregular-shaped follicles such as tube-like, deeply infolojed, U-shaped and branched. Fergus o n ('10/11) found irregular-shaped follicles to present diverticula in Elasmobranchs. U h le $\mathrm{nhuth}$ and $\mathrm{K}$ a r n s ('27) suggested that the irregular-shaped follicles with diverticula may be composed of several small follicles, in Amblystoma. C h a r i p pe r ('29) described the formation of nipples in several follicles in thyroid glands of Necturus maculotus. Recently, some authors gave two different interpretations to such irregular-shaped follicles-branching tubular follicles and those with several diverticulums-found in the lobule of the human thyroid gland, especially in that of the infant gland. The irregular-shaped follicles have been called the "Zentralkanälchen" (Klose, '16; A s ch of $\mathrm{I}$, '25) and said to produce new follicles in the lobule. On the other hand, $\mathrm{H}$ a $\mathrm{m} \mathrm{me} \mathrm{r}$ and L o e s c h c ke ('34) interpreted such irregular-shaped large follicles and their surrounding follicles in the lobule to represent the collecting duct system of the exocrine gland, whose cavities were found to communicate with each other, by preparing wax plate reconstruction models.

The present study indicates that in reptiles especially in Caretta caretta olivacea, Elaphe climacophora and Natrix tigrina tigrina, irregularshaped follicles were often found as multilocular sacs or with many pockets in their walls. It was found by observing carefully consecutive serial sections that follicles like the collecting duct system and "Zentralkanälchen" ảo not exist as an usual constant formation. The frequency of occurrence of such irregular-shaped follicles varies from case to case even in the same species. Also, in one of 8 cases of pigeon's thyroid glands, these irregular-shaped follicles were numerously seen. Furthermore, it may be said that the irregularshaped follicles resembling collecting ducts and central canals are not always characteristic for the human thyroid gland.

Most of the follicles represent independent and closed structures, completely separated from each other (Sobotta, '15 in human). This has been described also in lower vertebrates by Goode y ('10, in sharks), Sch a ffe r ('06, in Myxine), Cole ('05, in Myxine) and Ma u r r (1888, in amphibians; 1886, in fishes). Heiden ha in ('21) classified the thyroid glands of mammals into two types, associerter Typ and dissocierter Typ. In the former, follicles connect 
often with each other by their wall without communication of their cavities, and in the latter, they are completely separated from each other. Y a g i z a wa ('56) confirmed this fact with mammalian thyroid glands. The present study indicates that the follicles are completely separated in most of the species examined (figs. 4, 5, 6 and 11), but appear rarely in association only in the case of pigeons and frequently in the embryonic stages of domestic fowls and Agkistrodon blomhoffii. From this fact, it may be supposed that the association of follicles is a pattern characteristic for thyroid glands to grow further. Y a g i z a wa ('56), T a k i ('58) and $\mathrm{S} \mathrm{u} \mathrm{gi} \mathrm{y} \mathrm{a} \mathrm{ma}$ et al. ('59), interpreted it to be a sign of proliferation, present and past, of follicles through budding processes.

Follicle Epithelium-is different in form in various species of lower vertebrates. Some authors reported as follows. Fergus on ('10/11) that the epithelium is generally columnar but low in follicles filled with colloid in Elasmobranchs; $\mathrm{N}$ a c c a r a t i ('22) that the follicle cells are in general cubical, rarely columnar or squamous in Emys europaea; Bo u rne ('35) that the epithelium is cubical in Egernia kingii, and $\mathrm{He} 1 \mathrm{lb}$ a $\mathrm{m}$ ('36) that the epithelium is cubical to columnar in snakes. Various factors that influence the height of the follicle epithelium have been reported. Gudernatsch ('11) found in fishes that the epithelium flattens with age but the age cannot be the only factor and considered rather that this may be due to the different age of the follicles. Also it has been believed in thyroid glands of lower vertebrates that the epithelium is highly columnar in release of colloid, cubical to low columnar in secretion of colloid, and squamous in storage of colloid ( $\mathrm{K}$ o r e nc h e w s ky, '23, in pigeons; W a t z ka, '34, in fowls; W e i g m a n n, '32, in lizards, Eg g e rt, '34, in newts; $\mathrm{Klu} \mathrm{mp} \mathrm{p}$ and $\mathrm{Eg} \mathrm{gert}$, '34, in Ichthyophis glutinosus). Further, B a r g ma n n ('39) has summarized the changes of the follicle epithelium appearing in thyroid glands of lower vertebrates, which are caused by several factors such as the seasonal cycles, surrounding world, environmental temperature, beam of light and nutrition.

The present results showed that: in birds, the epithelium is low cubical to low columnar (table 1) and of the form usually found in the thyroid glands of mammals: in reptiles, the epithelium becomes far higher (table 1, figs. 4, 6, 7 and 20), and especially so in snakes and Clemmys: in Caretta caretta olivacea, however, the epithelium is variable in different follicles and even in the same or one follicle. 
It is highly columnar on one side of the follicle and squamous on the other. In small reptiles, the epithelium is low cubical. In amphibians, the epithelium is often low cubical and in fishes always more flattened. No seasonal change and no sex difference are distinctly found (table 1).

The nuclei of the follicle cells show distinctly no change characteristic for the lower vertebrates (figs. 16 to 23). However, it was found that the nuclei are generally larger in Urodela than in Anura and also so in comparing them with those of other lower vertebrates (fig. 10). They are generally round to oval, but their form changes with the form of the follicle cells. When the follicle cells are either columnar or flattened, the nuclei become more elliptical, with their long axis parallel to that of the cell. Their chromatin reticulum is moderately dense without containing distinct nucleoli. The nuclei usually lie at the base of the cell (snakes and Clemmys) or near it (most other species). This is in agreement with the data of Gudernatsch ('11, in bony fishes), Fergus on ('10/ 11, in Elasmobranchs), $\mathrm{Natc}$ a r a i ('22, in Emys), $\mathrm{C}$ hari p per ('29, Necturus maculosus) and B o u r n e ('35, Egernia kingii). Neither mitotic figures nor amitotic figures are found in the glands of adults of lower vertebrates examined.

The cytoplasm is generally granular and stained faintly red purple with periodic acid-Schiff's technique. Furthermore, it contains sometimes a single or a few droplets, large and small, which are stained deeply red purple with the same technique (fig. 23). The occurrence of these droplets have been reported in domestic fowls to be one of the signs of stimulation of the thyroid gland by an increased secretion of thyrotropic hormone in the pituitary (D vosk in, '47).

Brown pigment granules are found in the supranuclear zone in a few cases of Elaphe quadrivirgata and Natrix tigrina tigrina. They may be interpreted to be a kind of the "Abnützungspigment" which occurs in advanced age. Olive rea u ('57) found in tunnies that the follicle cells contain brown black pigments.


seldom seen in the thousands of follicles examined. $\mathrm{Ch}$ a r i p e r ('29) divided the follicle cells into chief cells and colloid cells in Necturus maculosus. S e v e r in g h a u s ('33) stated for thyroid glands of ducks that the colloid cells represent degenerating cells. B o u r n e ('35) found no colloid cells in the thyroid gland of Egernia kingii. 
$\mathrm{Hellbaum}$ ('36) found in snakes the sparse scattering of colloid cells, which stain darkly with osmic acid. The present study shows that the colloid cells are found not always frequently, but rather only in a very small number. With periodic acid-Schiff's stain, they are red purple and the positivity remains unchanged by saliva digestion. The nuclei are slightly small and darkly staining and sometimes pyknotic. The cell bodies are slender. It is supposed that they represent degenerating cells or resting cells in agreement with the data found in mammalian thyroid glands (summarized by B a r g m a n n, '39).

$\mathrm{Hamperl}$ ('36) pointed out the occurrence of oncytes in follicles, which become enlarged markedly, with a honey-comb-like, granular cytoplasm and sometimes with jagged pyknotic nuclei, and interpreted their development to be due to degeneration. The present study indicated the sparse occurrence of cask-like cells in the follicle epithelium in some species (Clemmys japonica; Caretta caretta olivacea; Elaphe climacophora). It is supposed from the observation of occasional occurrence of pyknotic nuclei in them that these cells may represent degenerating types of follicle cell.

No intercellular canalicules or splits ( $\mathrm{Hirschlerowa,} \mathrm{'28,}$ Vrtel, '31; v. Hage n, '36), through which the colloid of follicles is discharged into the circulatory system, were found in the present study.

Interfollicular epithelial cells in a broad sense seem to include various categories (parafollicular cells, macrothyrocytes, argyrophilic cells, nh-cells and parenchymatous cells) of cells or their groups which are found between follicles or directly on the follicle walls and further between ordinary follicle cells. Eg gert ('38) and $\mathrm{B}$ a rgmann ('39) summarized the data concerning the histology, development and significance of these cells which have been reported in mammalian thyroid glands. Forsyth ('08) described that the interstitial cells are entirely wanting or present to a very limited number in the thyroid glands of birds. According to him, when present they occur either isolated or in groups, and are not to be distinguished from parathyroid cells, and should be referred to as interstitial or parathyroid cells. Eg gert ('38) cited that the interstitial cells are found also in the embryonic thyroid glands of fowls. Takashima and $\mathrm{Hashimoto}$ ('31) found the interfollicular epithelial cells in the thyroid gland in the 9 to $22 \mathrm{~mm}$ tadpole stages of Bufo formosus, at which stages the growth of follicles begins. 
Furthermore, the interfollicular epithelial cells have been described to be slightly larger with acidophilic nuclei, and to have no relation with formation of new follicles ( $\mathrm{Takash}$ i ma and $\mathrm{Hash}$ i moto). The present study leads us to a conclusion of the absence of interfollicular epithelial cells in the embryonic and postembryonic thyroid glands of lower vertebrates. Epithelial cells found between follicles are always merely tangential sections of follicles. No groups of parathyroid cells are found to be scattered as the interfollicular epithelial cells in the thyroid gland of the birds examined here.

Colloid-has been described to be almost the same in appearance as that found in the mammalian thyroid glands by different authors, viz., the colloid is also eosinophilic, homogeneous and shows more or less numerous vacuoles at its periphery ( $\mathrm{Na}$ a re r, 1899, in lizards; F e r g u s o n, '10/11, in Elasmobranchs; G u der $\mathrm{n}$ a t $\mathrm{s} \mathrm{c} \mathrm{h}$, '11, in bony fishes; $\mathrm{N}$ a c c a r a ti, '22, in Emys europaea; $\mathrm{Kr}$ a u s e, '23, in birds, reptiles, amphibians and bony fishes; $\mathrm{Uhlenhuth}$ and $\mathrm{Karns}$, '27, in Amblystoma maculatum; C h a r i p p e r, '29, in Necturus maculotus; $\mathrm{G}$ a s c a, '32, in Anas domestica; $\mathrm{B}$ o u $\mathrm{r} \mathrm{n}$ e, '35, in Egernia kingii; B a r g m a n n, '39, in sharks).

Recently, the colloid of the mammalian thyroid glands has been stained by periodic acid-Schiff's technique and its positivity has been interpreted to contain glycoprotein (D e m p s e y, '55). In the thyroid glands of the lower vertebrates examined here, the colloid shows also the same positivity (fig. 23) and remains unchanged by saliva digestion. The colloid in the gland of some of the snakes examined (Elaphe quadrivirgata, Elaphe climacophora) showed sometimes granularity. Ferguson ('10/11) also found fine granularity of colloid in Elasmobranchs.

Desquamated follicle cells in the colloid have been differently interpreted to be physiological or pathological, and further as postmortem change or as an artifact. Fergus on ('10/11) found extruded and disintegrating nuclei in the colloid of Elasmobranchs. Gudernatsch ('11) found follicle cells to be pushed off into colloid in bony fishes. N a c c a rati ('22) found often desquamated epithelial cells in the follicles of Emys europaea. The present data also reveal that a few degenerating follicle cells are physiologically found in colloid.

Erythrocytes have been reported to be found in the colloid of lower vertebrates. Ferguson (10/11), in Elasmobranchs and B a r g ma n n ('35) in Scyllium canicula, found physiologically more or 
less numerous erythrocytes in colloid, to which they were carried as a result of degeneration of the follicle walls. On the other hand, v. H a g e n ('36) found such bleeding in colloid of Anguilla to be due to injury in preparing histological specimens. Addison and $\mathrm{R}$ ichter ('32) interpreted the bleeding in the central part of the thyroid gland of Xiphias gladius to be not due to the injury. Gudernatsch ('11) also found erythrocytes in the colloid of bony fishes and interpreted that the wall of the capillaries lying next to the follicle epithelium is ruptured by pressure and erythrocytes are carried through an injured wall. In one case of Corvus corone orientalis in the present study, a large peripheral follicle was found to be filled completely by erythrocytes with no injured area in the wall. This may suggest a rapid repair in the injured area, and at the same time that the bleeding reported by some authors is not physiologically usual.

Connective Tissue-The capsule has been found also in the thyroid glands of lower vertebrates ( $\mathrm{N}$ a c c a r a t i, '22, Emys europaea; $\mathrm{Kr}$ a u se, '23, birds, reptiles and amphibians; Bu s si, '29, lower tetrapods; Novotni, '31, fowls; B o u rne, '35, Egernia kingii). $\mathrm{Naccarati}$ ('22) and $\mathrm{Kra}$ us e ('23) found pigment cells in the capsule of Emys europaea and lizards. Elastic fibers are also found more or less abundantly here ( $\mathrm{N} \mathrm{a} \mathrm{c} \mathrm{carati,} \mathrm{'22,} \mathrm{Emys} \mathrm{europaea;}$ Novotni, '31, fowls). No capsule is found in the thyroid glands of fishes ( $\mathrm{Gud}$ e r nat s ch, '11). The present results show the presence of more or less developed capsules in the thyroid glands of lower vertebrates, except in those of fishes. In the amphibian thyroid glands examined it was found to be far less developed than in others. The capsule of these different species are connective tissue arranged in layers, containing argyrophilic fibers, with or without a small amount of elastic fibers.

B o z z i (1895) described that the connective tissue found within the thyroid gland is far less abundant in reptiles and birds than in mammals. The interlobular connective tissue was reported to be found as connective tissue septa (Novotni, '31, fowls; Nacc a r a ti, '22, Emys europaea; B o u rn e, '35, Egernia kingii). N a cc a rati found elastic fibers in them.

The present results reveal that the interstitial connective tissue is far less developed in different species of the lower vertebrates examined and further the interlobular connective tissue is almost absent (figs. 1 to 13) except in Caretta caretta olivacea. The inter- 
stitial connective tissue contained argyrophilic fibers which surround directly the follicles as a thin layer. The layer has been described as the "Grenzschicht" by B a r g m a n n ('39) and B u c h e r ('40) (figs. 4, 5,6 and 11). On the other hand, $\mathrm{Bozzi}$ (1895) found the basal membrane in follicles of birds and reptiles but not in those of frogs. Krause ('23) observed the membrana propria in follicles of pigeons. Schaffer ('06) found no distinct membrana propria in follicles of Myxine. Bussi ('29) found reticular membranes around follicles which developed best in birds, better in reptiles and least in amphibians.

No pigment cells are found in the interstitial connective tissue of the thyroid glands of the species examined here. On the other hand, $M$ a u r e r (1899) found numerous chromatophors here in lizards, Eg g e r t ('35/36) in lizards, $A^{\prime} d \mathrm{~d}$ is o $\mathrm{n}$ and $\mathrm{R}$ ichter' ('32) in sworä-fishes, and v. Ha ge n ('36) in eels. No fat tissue were found here except in the thyroid gland of Rana nigromaculata nigromaculata, and further no other tissues such as muscle fibers and cartilage were found.

Blood Vessels-N a c c a r a i ('22) found in Emys europaea that the arteries form networks within the capsule and enter the interior of the gland further to form capillary networks, while the veins form dense networks on the glandular surface. Tsusaki and Y a t a be ('31) reported well-developed networks of veins within the thyroid gland of Urodela. The present results indicate the following: Within or beneath the capsule, more or less numerous well-developed arteries run and enter the interior of the gland and gradually ramify to capillaries. Veins have generally no muscle fibers and consist of the intima and adventitia. In amphibian thyroid glands, the blood vessels are generally far less developed.

$\mathrm{S}$ u g i y a ma ('40;' 42 ; '50) found the sphincter apparata at the branching points of the arteries within the thyroid gland and its capsule of albino rats, mice and rabbits. O h id a ('53) in guinea pigs and Sato ('55) in hamsters reported the presence of the same structure in the same places. According to them, the sphincter apparata appear as a funnel-shaped structure consisting of endothelium and muscle fibers circularly arranged, of which the apex projects into the cavity of the main artery and the base is situated on the starting point of the branch artery. In lower vertebrates, it was found that almost the same structures are found in some species of birds and reptiles (figs. 16 to 21), but not in amphibians 
and bony fishes (table 1). In birds, Corvus corone orientalis has them most frequently, Columba livia domestica frequently, and Gallus gallus domesticus less frequently. In reptiles, Elaphe climacophora has them most frequently, Agkistrodon blomhoffii frequently and Clemmys japonica less frequently.

Other special structures such as the intima thickenings (Intimaverdickung-I s e n s c h m id, ' 10 ; S a n d e r s o n-D a m be r g, '11; in human materials) and the artery buds (Arterienknospe-S $\mathrm{ch} \mathrm{midt}$, 1894; Hesselberg, '10; I s e n s chmid, ' 10 ; all in human materials; Sobotta, '15, in dogs and cats) are not found in the thyroid gland of the lower vertebrates examined. Modell ('33) found cushions composed of smooth muscle fibers which occur at the junction of an arterial trunk and its branch in the thyroid gland of dogs, and $\mathrm{K} \mathrm{ux}$ ('35) lip- or sphincter-like structures which appear at the branching points of large arteries in the thyroid glands of dogs and human. Bozzi (1895) could find no arterial buds in the thyroid glands of birds, reptiles and frogs. It is supposed that these structures serve as a regulator of blood supply which is related to the proauction of thyroid hormone.

Capillaries are abundant within the thyroid gland (figs. 16 to 23). This is in agreement with the data of mammalian thyroid glands. The capillaries form more or less dense networks closely around the follicles and become engorged in the cases of dominant occurrence of irregular-shaped follicles, regardless of difference of the species examined. The capillaries are surrounded circularly by argyrophilic fibers and the endothelium is not in direct contact with the follicle epithelium. B a r g a n n ('39) also found the delicate basal membrane between the follicle epithelium and endothelium in the thyroid gland of sharks, while Addis on and R ichter ('32) reported the direct contact of both epithelia in sword-fishes.

Epithelial Inclusions-In mammals, enigmatic structures and cysts are often included within the thyroid glands and have been reported to be of branchiogeneous, especially ultimobranchial origin. Eg gert ('35/36) found cysts of thyroglossal duct origin in the thyroid glands of lizards. In lower vertebrates also it was found that cysts and epithelial pearls occur in some species of the reptiles (Clemmys japonica and Elaphe climacophora) (figs. 14 and 15). The origin of these cysts and pearls remains unsettled, but it is probable that they are of branchiogeneous origin. 


\section{Summary}

Thyroid glands of lower vertebrates including several species of birds, reptiles, amphibians and fishes were histologically investigated and the data obtained were discussed by comparing with the data known of mammalian thyroid glands.

1. The thyroid glands of lower vertebrates are composed of independent, separated closed epithelial sacs-follicles-which are generally round to oval and larger in the periphery than in the center.

2. Follicles of the embryonic or maturing thyroid glands are often associated with each other by direct connection of their walls without open communication of their cavities, and form follicle groups. This may suggest the proliferation, present and past, of follicles through budding process.

3. It was difficult to find any significant difference in follicles in relation to sex and season. The follicles are generally small in birds such as crows, pigeons, domestic fowls, swallows and sparrows. On the other hand, the follicles are considerably large in Chelonia and snakes. The follicles of lizards are small. The follicles of amphibians and small fishes are also small. It is supposed that the size of iollicles may depend partly upon the body weight and length of animals used.

4. In some cases of Chelonia and snakes, very irregular-shaped follicles are very often or sometimes found. Some of them are so multilocular and remind one of the presence of the collecting duct system and the "Zentralkanälchen" in the gland. The frequent occurrence of them, however, does not represent the usual constant pattern of the gland.

5. It was difficult to find any significant change in follicle cells in relation to sex and season. The follicle cells are cubical to columnar, especially highly columnar in Clemmys and snakes. In fishes, the follicle cells are generally low cubical. The nuclei are round to oval, containing a moderately dense chromatin reticulum and the nucleoli are indistinct. The cytoplasm contains sometimes periodic acid-Schiff positive secretory droplets. In a few cases of snakes, the cytoplasm contains brown black pigment granules, which may be considered as the "Abnützungspigment." Colloid cells are found also in a small number, and stained red purple by periodic acid-Schiff's stain. 
6. No parafollicular cells are found.

7. Colloid is homogeneous, but granular in some species (Elaphe climacophora and E. quadrivirgata) of snakes, more or less extensively vacuolated at the periphery, and stained red purple by periodic acidSchiff's technique. The colloid contains rarely a small number of degenerative follicle cells and erythrocytes.

8. The capsule is more or less developed except in fishes, containing argyrophilic fibers and in some species of snakes a small amount of elastic fibers. The interlobular connective tissue is generally not found except in Caretta. The interstitial connective tissue contains abundant argyrophilic fibers but no elastic fibers generally. A small amount of elastic fibers are found here only in some species of snakes. The argyrophilic fibers enclosed the follicles as a thin layer, the "Grenzschicht."

9. The arteries for the thyroid glands run within or beneath the capsule, entering the interior of the gland to ramify into smaller branches and the veins accompany the arteries. The capillaries form dense networks around the follicles and sometimes appear as sinusoidal capillaries.

At the branching points of the arteries found within the capsule and the gland, funnel-shaped sphincter apparata are more or less often found in some species of birds and reptiles (crows, pigeons, domestic fowls, swallows and sparrows; Clemmys, Elaphe climacophora and Agkistrodon blomhoffii), and are composed of the endothelium and smooth muscle fibers circularly arranged. Their apex projects towards the cavity of the main artery and their base is situated at the branching point.

10. Within the capsule or within the gland of some species of reptiles (Clemmys and Elaphe climacophora), single-layered to stratified epithelial cysts and pearls are found. It is supposed that they are of branchiogeneous origin.

\section{Literature Cited}

Addison, W.H.F. and M.N. Richter: A note on the thyroid gland of the sword-fish (Xiphias gladius L.). Biol. Bull. Mar. Biol. Labor. Wood's Hole, 63: 472-476, 1932 (cited from B a r g m a n n, '39).

Aschoff, L.: Vorträge über Pathologie gehalten an den Universitäten und Akademien Japans im Jahre 1924. 1-309, Gustav Fischer, Jena, 1925.

B a r gmann, W.: Die Schilddrüse. Handb. mikr. Anat., 6:2 Tl., 1-136, Julius Springer, Berlin, 1939. 
: Über intrafollikuläre Blutungen in der Schilddrüse der Selachier. Anat. Anz., 88: 41-45, 1935.

Benazzi : cited from Bargmann ('39).

Bi ondi: Beitrag zur der Struktur und Funktion der Schilddrüse. Berliner Klin. Wschr., 25 : 954-955, 1888.

Bourne, G.: An unusual thyroid gland in a race of lizards (Egernia kingii) from Eclipse Island, W. Australia. J. Anat., 69:515-519, 1935.

B o z zi, E.: Untersuchungen über die Schilddrüse. Histologie-Sekretion-Regeneration. Beitr. path. Anat., 18:125-173, 1895.

Bucher, O.: Intraepitheliale Kapillaren im Follikelepithel der Schilddrüse. $Z$. Zellforsch., $30: 432-437,1940$.

Bussi, E.: Il connectivo della tiroide dei Tetrapodi inferiori. Monit. zool. ital, $40: 172-178,1929$. (Anat. Ber., 20:50, 1930/31).

$\mathrm{Ch}$ aripper, H.A.: Studies on amphibian endocrines. 1. The thyroid gland of Necturus maculotus. Anat. Rec., $44: 117-141,1929$.

Cole, F. J.: Notes on Myxine. Anat. Anz., $27: 323-326,1905$.

Cowdry, E. V.: Textbook of Histology. Henry Kimpton, London, 1934.

Dempsey, E.W.: Microscopic anatomy of the thyroid. Werner's the thyroid. 106-118, A Hoeber-Harper Book, N. Y.C., 1955.

Dvoskin, S.: Intracellular colloid droplets as a basis for thyrotrophic hormone assay in the chick. Endocrin., 41:220-229, 1947.

E g gert, B.: Zur Überwinterung der Larven von Molge alpestris Laur. unter besonderer Berücksichtigung des Verhaltens der Schilddrüse. Z. Zool., 145: 399-424, 1934.

: 1935/36 (cited from Bargmann, '39).

: Morphologie und Histphysiologie der normalen Schilddrüse. Zwangl. Abhandl. aus dem Gebiete der Inneren Sekretion. 3:1-113, Johann Ambrosius Barth, Leipzig, 1938.

Ferguson, J.S.: The anatomy of the thyroid gland of Elasmobranchs, with remarks upon the hypobranchial circulation in these fishes. Am. J. Anat., 11: $151-210,1910 / 11$.

Forsyth, D.: The comparative anatomy, gross and minute, of the thyroid and parathyroid glands in mammals and birds. J. anat. and physiol., $42: 141-169$, 302-319, 1908.

Galle otti, G.: Beitrag zur Kenntnis der Sekretionserscheinungen in den Epithelzellen der Schilddrüse. Arcin. mikr. Anat., 48:305-328, 1897.

G a s ca, L.: Richerche sulla istofisiologia della ghiandola tiroide di Anas domestica. Arch. ital. Anat., 30:102-118, 1932. (cited from Bargmann, '39).

G'e"g e n baur, C.: Vergleichende Anatomie der Wirbeltiere mit Berücksichtigung der Wirbellosen. 2:250-254, W. E n g e $1 \mathrm{~m}$ a n n, Leipzig, 1901.

Geur, C.: Morphologie und Histologie der Pferdeschilddrüse (unter Berücksichtigung des Einflusses von Alter, Geschlecht, Rasse, Jahreszeit und besonders vom Jodgehalt). Z. Anat. u. Entw. -gesch., 95:473-496, 1931.

Golds mith, E. D.: Phylogeny of the thyroid: descriptive and experimental., Ann. New York Acad. Sci., $50: 283-316,1949$.

Goodey, T.: Vestiges of the thyroid in Chlamydoselachus anguineus, Scyllium catulus and canicula. Anat. Anz., 36:104-108, 1910.

Gorbman, A.: Comparative anatomy of the thyroid. Werner's the thyroid. 104106, A Hoeber-Harper Book, N. Y.C., 1955 a.

- Some aspects of the comparative biochemistry of iodine utilization and 
the evolution of thyroidal function. Physiol. Rev., 35:336-346, $1955 \mathrm{~b}$.

Gudernatsch, J.F.: The thyroid gland of the teleosts. J. Morph., 21:709-782, suppl., 1911.

H a mmer, E. and H. Loeschcke: Der feinere Bau der Schilddrüse und die sich aus ihm ergebenden Vorstellungen über das Wesen der sogenannten Proliferationsknospen. Zbl. path., 60: Erg. -H., 204-215, 1934.

$\mathrm{H}$ a m per 1, H.: Über das Vorkommen von Onkocyten in verschiedenen Organen und ihren Geschwülsten (Mundspeicheldrüsen, Bauchspeicheldrüse, Epithelköperchen, Hypophyse, Schilddrüse, Ei!eiter). Virchows Arch., 298:327-375, 1936.

Heidenhain, M.: Über verschiedene Typen im Bau der Schilddrüse. Anat. Anz., Erg. -Bd. 54, 141-151, 1921.

$\mathrm{He} l \mathrm{lb}$ a u m, H.W.: The cytology of the snake thyroids following hypophysectomy, activation and ultracentrifuging. Anat. Rec., 67:53-67, 1936.

$\mathrm{H}$ es s e lberg, C.: Die menschliche Schilddrüse in der fetalen Periode und in den ersten 6 Lebensmonaten. Frankf. Z. Path., 5:322-350, 1910.

Hirschlerowa, Z.: Mikroskopisch-anatomische Untersuchungen an der Amphibienschilddrüse mit besonderer Berücksichtigung ihres Golgiapparates. Z. Zellforsch., 6:234-256, 1928.

Is enschmid, R.: Zur Kenntnis der menschlichen Schilddrüse im Kindesalter, mit besonderer Berücksichtigung der Herkunft aus verschiednen Gegenden im Hinblick auf die endemische Struma. Frankf. Z. Path., 5:205-252, 1910.

K1ose, H.: Die pathologisch-anatomische Grundlagen der Basedow'schen Krankheit, nach vergleichend pathologischen und klinischen Studien. Bruns Beitr. klin. Chirur., 102:1-12, 1916.

$\mathrm{K} 1 \mathrm{umpp}$, W. and B. Eg gert: Die Schilddrüse und die branchiogenen Organe von Ichthyophis glutinosus L.. Z. zool., 146:329-381, 1934.

Korenchewsky, V.: Glands of internal secretion in experimental avian BeriBeri. J. Path., 26:382-388, 1923.

Krause, R.: Mikroskopische Anatomie der Wirbeltiere in Einzeldarstellungen. W. de Gruyter u. Co., Berlin u. Leipzig, 1923.

$\mathrm{Kux}$, E.: Über muskulöse Drosselvorrichtungen ("Zellknospen", "Polster") in den Arterien der Schilddrüse. Virchows Arch., $294: 358-364,1935$.

Maurer, F.: Schilddrüse und Thymus der Teleostier. Morph. Jb., 11:129-175, 1886.

- : Schiddrüse, Thymus und Kiemenreste der Amphibien. Morph. Jb., 13: 296-384, 1888.

- Die Schilddrüse, Thymus und andere Schlundspaltenderivate bei der Eidechse. Morph. Jb., $27: 119-172,1899$.

- Die Schilddrüse. Handb. vergl. exper. Entw.-lehre d. Wirbeltiere. $2: 1$ T1., 127-131, Gustav Fischer, 1906.

Mode11, W.: Observations on the structure of the blood vessels within the thyroid gland of the dog. Anat. Rec., $55: 251-269,1933$.

$\mathrm{Naccarati}$ S.: Contribution to the morphologic study of the thyroid gland in Emys europaea. J. morph., 36:279-297, 1922.

Novotni, G.: Die Endokrindrüsen des Huhns. Közlem. az összehasonlitó élet és Kórtan Köreböl, 24:611-655, 1931 (Anat. Ber., 25: 301-302, '32/33).

$\mathrm{Ohida}$ S.: On the sphincter in the artery of the thyroid gland of the guinea pig. Fol. anat. jap., $25: 195-199,1953$.

Olivereau, M.: Étude anatomique et histologique de la glande thyroide du thon (Thunnus thynnus L. et Germo alalunga). Bull. Soc. Zool. France, LXXXII, 
401-417, 1957.

P i s ch inger, A.: Kiemenanlagen und ihre Schicksale bei Amnioten. Handb. vergl. Anat. Wirbeltiere, 3:279-348, Urban and Schwarzenberg, Berlin u. Wien, 1937.

Sa nderson-D a mber g, E.: Die Schilddrüse vom 15. bis 25. Lebensjahre. Frankf. Z. Path., 6:312-334, 1911.

Sat o, T.: On the sphincter apparata in the artery of the thyroid gland of the hamster. Okajimas Fol. anat. jap., $27: 355-360,1955$.

Sch a f fer, J.: Berichtigung, die Schilddrüse von Myxine betreffend. Anat. Anz., $28: 65-73,1906$.

S chi m kewit s ch, W.: Lehrbuch der vergleichenden Anatomie der Wirbeltiere. Die Schilddrüse (Glandula thyreoidea). 376-379, Schweizerbart., Stuttgart, 1910.

Schmidt, M. B.: Über Zellknospen in den Arterien der Schilddrüse. Virchows Arch., $137: 330-348,1894$.

Severing haus: Cytological observations on secretion in normal and activated thyroids. Z. Zellforsch., $19: 653-680,1933$.

Sobotta, J.: Anatomie der Schilddrüse (Glandula thyreoidea). Handb. Anat. Menschen., 6:3 Abt., 4 Tl., 155-220, Gustav Fischer, Jena, 1915.

$\mathrm{Sug}$ i y a ma, S.: On the sphincter in the artery of the thyroid gland of the albino rat. Nagoya J. Med. sci., $13: 387-390,1940$.

- On the sphincter in the artery of the thyroid gland in the mouse. Jap. J. Med. Sci., Part 1, Anat., $9: 149-152,1942$.

- On the postnatal histogenesis of the thyroid gland of the rabbit. 2. On the sphincter in the artery system of the thyroid gland. Okajimas Fol. anat. jap., 23: 65-66, 1950.

$\mathrm{Sugiyama}$, S. and T. Sato: Studies of the histogenesis of the thyroid gland of the guinea pig. II. Quantitative measurements of the follicles and correlation with function. Anat. Rec., $120: 379-394,1954$.

S.u g i y a ma, S., A. Taki, A. Nakano, N. Sugi y a ma and Y. Y a mamoto: Histological studies of the human thyroid gland in middle and late prenatal life. Okajimas Fol. anat. jap., 33:75-85, 1959.

Takashima, R. and K. Hashi moto: Über dei Entwicklung der Schilddrüse bei den Japanischen Kröten (B. formosus). Kaibo Zasshi., 4:1450-1465, 1931.

Taki, A.: Histological studies of the prenatal development of the human thyroid gland. Okajimas Fol. anat. jap., 32:65-85, 1958.

Tsusaki, T. and T. Y a t a be: Über die Blutversorgung der Schilddrüse bei den Urodelen. Keijo J. Med., 2: 44-52, 1931.

Tsutsui, C.: Studies on the thyroid follicles. Igaku Kenkyu, 28: 249-278, 1958.

Uhlenhuth, F. and H. Karns: The follicular pattern of the thyroid gland in Amblystoma maculatum. Anat. Rec., $35: 27,1927$.

v. Hagen, F.: Die wichtigsten Endocrinen des Fussaals. Zool. Jb., 61:467-538, 1936.

Vrte 1, S.: Histologische Untersuchungen über die Schilddrüse. Die Selachierschilddrüse. Bull. Acad. polon. Sci. cl. Sci. math. et natur. Ser. B. 1931, No, 2, 155-200 (cited from Barg m a n $\mathrm{n}$, '39).

Wat z ka, M.: Physiologische Veränderungen der Schilddrüse. Z. mikr. anat. Forsch., 36:67-86, 1934.

We ge li n, C.: Schilddrüse. Handb. spez. path. Anat. u. Hist., 8:1-37, Julius Springer, Berlin, 1926.

W e i g m a n n, R.: Jahrescyclische Veränderungen im Funktionszustand der Schilddrüse und im Stoffumsatz von Lacerta vivipara JACQ. Z. Zool., 142:491-50؟, 
1932.

Wi ed e rs he i m, R.: Vergleichende Anatomie der Wirbeltiere. Glandula thyreoidea. 413-415, 6. Aufl., Gustav Fischer, Jena, 1906.

Yag i $z$ awa, T.: The follicular pattern in the thyroid gland of maturing and mature mammals. Okajimas Fol. anat. jap., 29:93-116, 1956.

\section{Explanation of Plate Figures}

1 to 13: Photomicrographs of the thyroid glands of lower vertebrates.

1 Corvus corone orientalis. Ciaccio. Hematoxylin-eosin. $\times 80$.

2 Hirundo rustica gutturalis. Ciaccio. Hematoxylin-eosin. $\times 80$.

3 Passer montanus saturatus. Ciaccio. Hematoxylin-eosin. $\times 80$.

4 Clemmys japonica. Adult. Zenker-formol. Biel s chows ky's silver impregation. $\times 80$.

5 Clemmys japonica. Infant. Zenker-formol. Biel s chow sky's silver impregnation. $\times 80$.

6 Elaphe conspicillata. Zenker-formol. Biels chows ky's silver impregnation. $\times 80$.

7 Agkistrodon blomhoffii. Ciaccio. Hematoxylin-eosin. $\times 80$.

8 Eumeces latiscutatus latiscutatus. Zenker-formol. Hematoxylin-eosin. $\times 80$.

9 Gecko japonicus. Ciaccio. Hematoxylin-ensin. $\times 80$.

10 Onychodactylus japonicus. Ciaccio. Hematoxylin-eosin. $\times 80$.

11 Hyla arborea japonica. Zenker-formol. Bi e l s chow sky's silver impregnation. $\times 80$.

12 Plecoglossus altivelis. Zenker-formal. Hematoxylin-eosin. $\times 80$.

13 Carassius auratus. Bouin. Hematoxylin-eosin. $\times 80$.

14 and 15: Enigmatic structures (single-layerd to stratified epithelial cysts) are seen in the thyroid gland of reptiles.

14 Clemmys japonica. Ciaccio. Hematoxylin-eosin. $\times 160$.

15 Elaphe climacophora. Ciaccio. Iron hematoxylin. $\times 80$.

16 to 21: Photomicrograhs of the thyroid glands of lower vertebrates. Sphincter apparata are found at the branching points of the arteries. The sphincter apparata appear as two lips in longitudinal section (arrows) and as a bud in tangential section (asterisk). The nuclei of smooth muscle fibers, which are arranged circularly as the main component in the sphincter apparata, are found as small round nuclei.

16 Corvus corone orientalis. Ciaccio. Hematoxylin-eosin. $\times 340$.

17 Hirundo rustica gutturalis. Ciaccio. Hematoxylin-eosin. $\times 340$.

18 Passer montanus saturatus. Ciaccio. Hematoxylin-eosin. $\times 340$.

19 Agkistrodon blomhoffii. Ciaccio. Hematoxylin-eosin. $\times 340$.

20 Elaphe climacophora. Ciaccio. Hematoxylin-eosin. $\times 340$.

21 Clemmys japonica. Ciaccio. Hematoxylin-eosin. $\times 340$.

22: A thyroid gland of Caretta caretta olivacea. The follicle wall forms several small pockets. Ciaccio. Hematoxylin-eosin. $\times 480$.

23: A thyroid gland of Natrix tigrina tigrina. Periodic acid-Schiff positive secretory droplets (arrows) are seen in the apical, lateral and basal zones of the follicle cells. Zenker-formal. $\times 900$. 
Plate I



Y. Yamamoto 
Plate II
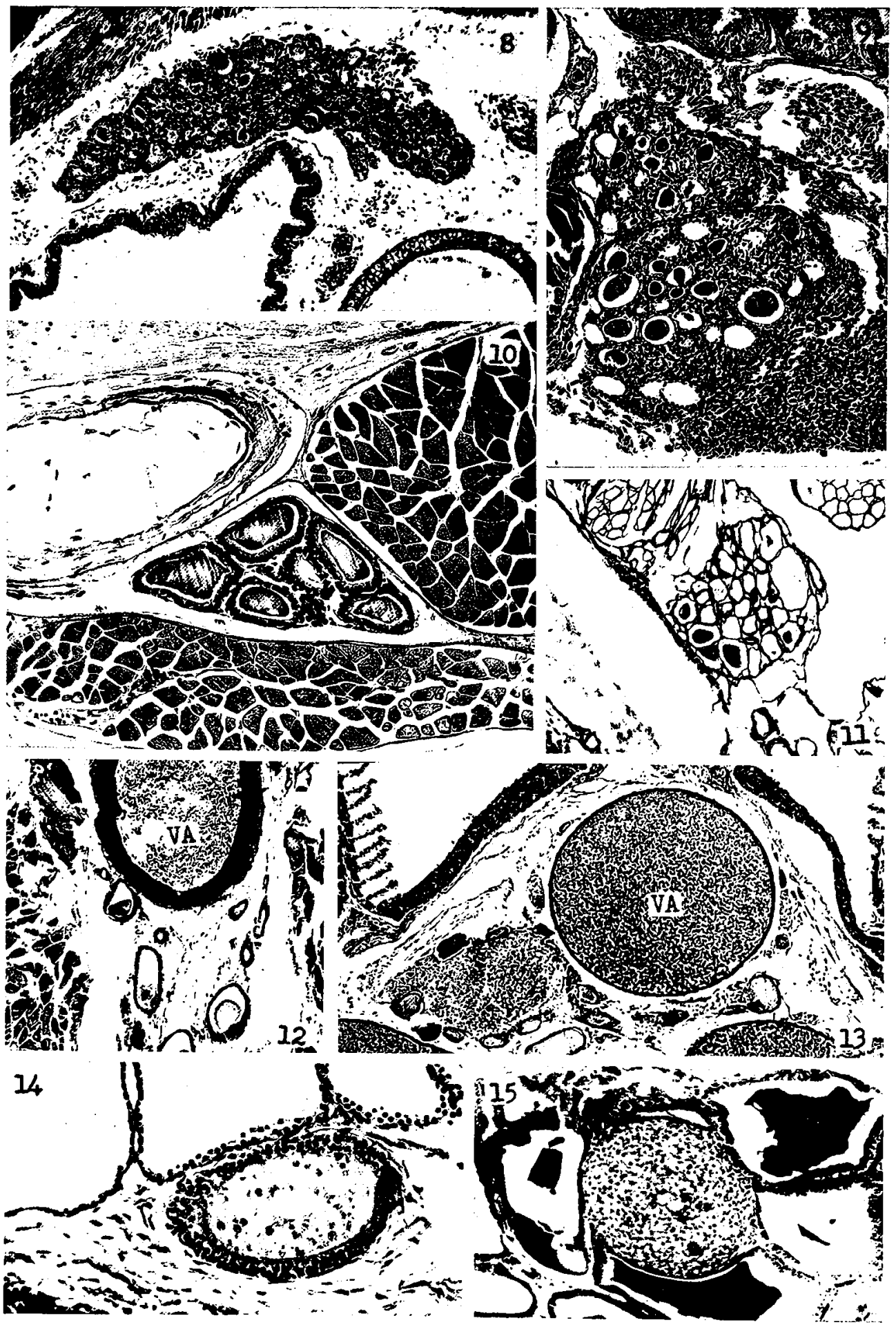

Y. Yamamoto 

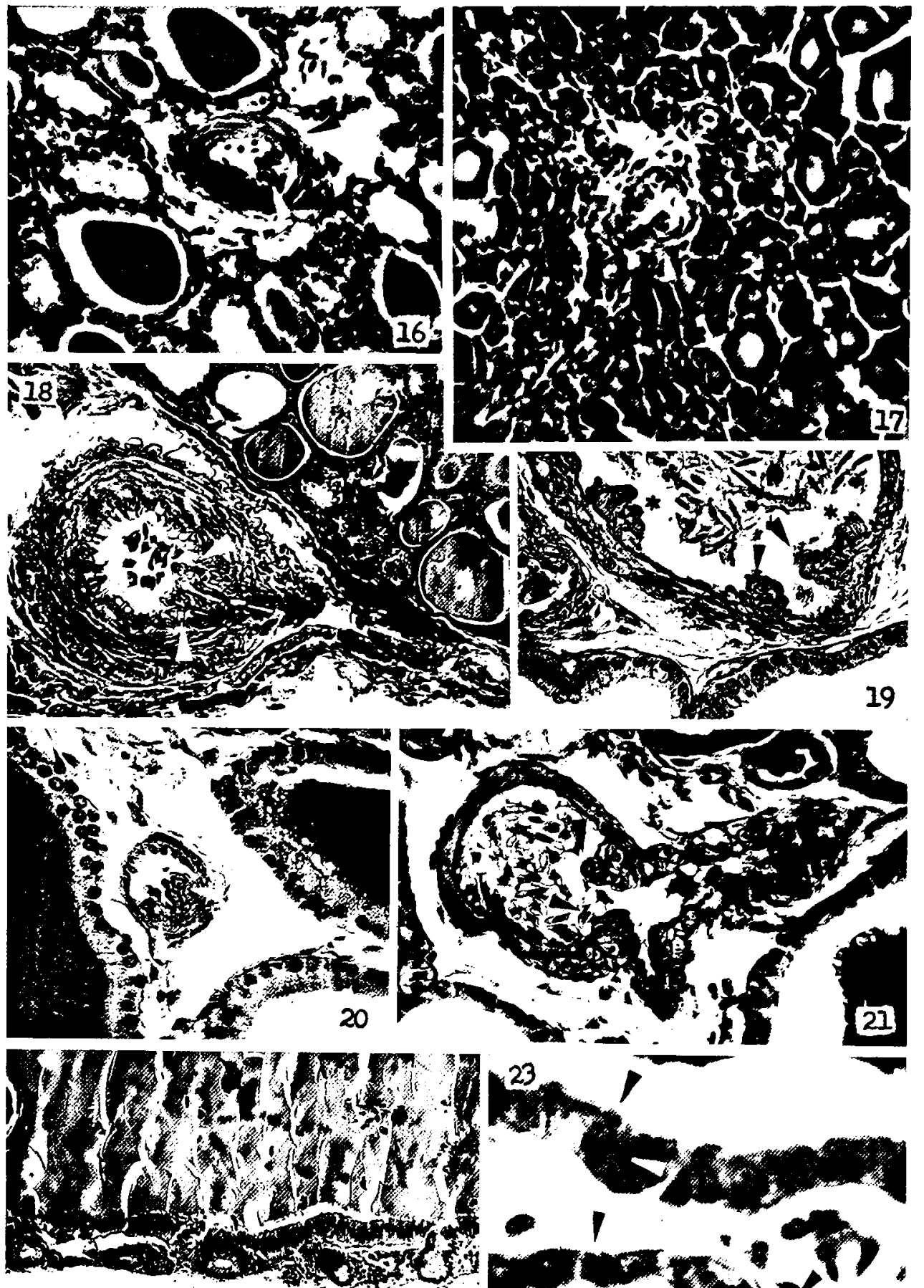

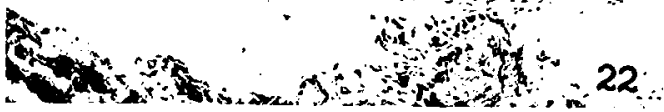



Y. Yamamoto 